\title{
Differential Response of Cowpea (Vigna unguiculata L.) Genotypes to Native Rhizobia in Tarai Region of Uttarakhand, India
}

\author{
Sonam BINJOLA ${ }^{1}$, Narendra KUMAR ${ }^{1}$, Gaurav MISHRA ${ }^{2 *}$ \\ ${ }^{1}$ G. B. Pant University of Agriculture and Technology, College of Agriculture, Department of Soil Science, Pantnagar-263 145, India; \\ gaurav.mishra215@gmail.com (*orrespondingauthor) \\ ${ }^{2}$ Rain Forest Research Institute, Jorhat-785001, Assam, India
}

\begin{abstract}
Cowpea is an annual legume, rich in protein, which plays a critical role in the lives of millions of people in developing countries. Limited work has been done, especially on the symbiotic efficiency of cowpea against the native soil rhizobia. Therefore, our study was conducted to compare the effect of native rhizobia on nodulation, yield and protein content of eight cultivars and two control varieties in Tarai region of Uttarakhand, India. Significant differences were observed among the cultivars tested in all the measured traits. Results of growth analysis indicated that 'PGCP-4' gave the highest number of nodules plant ${ }^{-1}$, nodule dry weight and protein content in grain, compared to both control varieties. Highest plant dry weight was recorded in 'Pusa Komal', while the highest grain yield was achieved in 'PGCP-6', followed by 'PGCP-12'. This study hereby recommends 'PGCP-6' and 'PGCP-12' cultivars, as they are more suitable in terms of yield against the rhizobia.
\end{abstract}

Keywords: dehydrogenase activity, nodule number, nodule dry weight, plant dry weight, yield, protein content

\section{Introduction}

Cowpea (Vigna unguiculata L.) is one of the most important grain legumes, constituting an integral component of the subsistence farming. Additionally, cowpea offers a rich source of protein (23-25\%), providing inexpensive and quality-diets for the people of developing countries. It also serves as a source of livestock, feed and soil ameliorant and thus contributes to food security, income generation and maintenance of the environment for a large number of resource-poor farmers. There are two important subspecies of cowpea viz unguiculata and sesquipedalis. The former is grown for its dry seeds, whereas the later is harvested at immature pod stage thus making it suitable for vegetable use. Among all the grain-legumes, cowpea is the most extensively cultivated, distributed and traded food crop in India (Ogbo, 2009; Agbogidi, 2011; Philips and McWalters, 1991), being of considerable nutritional and health value to man and livestock. Besides its higher protein and mineral content, cowpea also fixes atmosphere nitrogen through establishing a symbiotic relationship with nodule bacteria and maintains the fertility level of soil (Shiringani and Shimeles, 2011). In comparison to other grain-legume crop, cowpea shows remarkable tolerance to drought, an inherent property that makes it a promising cash crop in subsistence agriculture. Taken into consideration the economic importance of the crop, this investigation intends to screen eight cowpea genotypes against two control varieties with the following objectives: to study the influence of native soil rhizobia on nodulation, growth, yield and protein content of different cowpea genotypes.

\section{Materials and methods}

Field experiment was conducted at Seed Production Centre (SPC) of G. B. Pant University of Agric. \& Technology, Pantnagar, Uttarakhand. The soil was sandy loam having $\mathrm{pH} 7.4$, organic $\mathrm{C} 0.70 \%$, available $\mathrm{N}, \mathrm{P}, \mathrm{K}, 241$, $22.3,141 \mathrm{~kg} \mathrm{ha}{ }^{-1}$, respectively. The experiment was conducted in Randomized Block Design (RBD) with four replications, using eight different cultivars namely, PGCP-3, PGCP-4, PGCP-5, PGCP-6, PGCP-11, PGCP-12, PGCP13, PGCP-14 and two controls viz. Pant Lobia -1 and Pusa Komal. The basal application of $100 \mathrm{~kg} \mathrm{ha}^{-1} \mathrm{~N}$ P K fertilizer $(12: 36: 16)$ was done at sowing. Three plants per plot were uprooted carefully and nodules from the washed plant roots were separated and counted. After removing the nodules, nodules and plants were dried in the hot air oven at $70{ }^{\circ} \mathrm{C}$ for 72 hours and subsequently, their dry weights were recorded in $\mathrm{mg}$ plant $\mathrm{t}^{-1}$ and $\mathrm{g}$ plant ${ }^{-1}$, respectively. After harvesting, the grain yield and biological yield of individual plot was recorded. Straw yield $\left(\mathrm{kg} \mathrm{ha}^{-1}\right)$ was recorded by subtracting the grain yield from the total biological yield $\left(\mathrm{kg} \mathrm{ha}^{-1}\right)$. For protein analysis, the dried plant samples were finely grind in powder form. The nitrogen contents in grain samples were determined by Micro-Kjeldahl method (Jackson, 1967) and the protein content was estimated using nitrogen concentration in protein formula: 
336

Protein content $(\%)=\mathrm{N}$ content $(\%) \times 6.25$

Dehydrogenase activity was determined by the method given by Casida et al. (1964).

The laboratory and experimental data were analyzed by using standard procedure for a randomized block design with the help of computer applying analysis of variance (ANOVA) technique. The differences among treatments were compared by applying $\mathrm{F}$ test of significance at $5 \%$ level of significance or probability.

\section{Results and discussion}

The minimum number of nodules plant ${ }^{-1}(10.24)$ was formed on PGCP-5, while the maximum nodule number plant $^{-1}$ (39.83) was noted on PGCP-4. The varieties PGCP11 and PGCP-4 showed $27.2 \%$ and $75.8 \%$ significantly more nodules plant ${ }^{-1}$ than control varieties Pant Lobia-1 and Pusa Komal, respectively. All varieties were significantly poor compared with Pusa Komal, except PGCP-4; however, PGCP-12 and PGCP-13 were parallel to Pant Lobia-1. The varieties PGCP-3, PGCP-5, PGCP-6 and PGC-14 were significantly poor than Pant Lobia-1 (Tab. 1). Pusa Komal recorded $58.12 \%$ more nodule number plant ${ }^{-1}$ than other control variety of Pant Lobia-1. The experimental results revealed that the highest nodule dry weight of $464.41 \mathrm{mg}$ plant $^{-1}$ was shown by PGCP-4, while the lowest was recorded for PGCP-3 (219.99 mg plant $\mathrm{t}^{-1}$ ). The two genotypes viz. PGCP-4, PGCP-12 exhibited significantly more nodule dry weight plant ${ }^{-1}$ than the control variety Pant Lobia-1. PGCP-13 was at par with both control varieties.

Tab. 1. Physiological characters of cowpea as influenced by cultivar differences

\begin{tabular}{cccc}
\hline Varieties & $\begin{array}{c}\text { Nodule } \\
\text { number } \\
\left(\text { plant }^{-1}\right)\end{array}$ & $\begin{array}{c}\text { Nodule dry } \\
\text { weight } \\
\left(\text { mg plant }^{-1}\right)\end{array}$ & $\begin{array}{c}\text { Plant dry } \\
\text { weight } \\
\left(\text { g plant }^{-1}\right)\end{array}$ \\
\hline PGCP-3 & 11.41 & 219.99 & 10.21 \\
PGCP-4 & 39.83 & 464.41 & 9.86 \\
PGCP-5 & 10.24 & 229.08 & 10.41 \\
PGCP-6 & 14.41 & 253.16 & 8.90 \\
PGCP-11 & 28.83 & 287.24 & 11.60 \\
PGCP-12 & 20.08 & 417.91 & 11.39 \\
PGCP-13 & 21.66 & 303.08 & 12.06 \\
PGCP-14 & 10.66 & 256.41 & 10.08 \\
Pant Lobia-1 & 22.66 & 344.33 & 9.05 \\
Pusa Komal & 35.83 & 351.16 & 12.91 \\
SEm & 1.86 & 19.45 & 0.59 \\
CD at $5 \%$ & 5.40 & 56.46 & 1.72 \\
CV & 17.28 & 12.44 & 11.13 \\
\hline
\end{tabular}

The highest plant dry weight of $12.91 \mathrm{~g} \mathrm{plant}^{-1}$ was recorded in control variety Pusa Komal and the lowest, 8.90 g plant ${ }^{-1}$, in PGCP-6. Control variety Pusa Komal was significantly better than Pant Lobia-1 by showing 45\% higher plant dry weight. PGCP-11, PGCP-12 and PGCP13 were significantly better than Pant Lobia- 1 . The varieties PGCP-11, PGCP-12 and PGCP-13 were statistically comparable with the control Pusa Komal.

The highest grain yield of $2225.00 \mathrm{~kg} \mathrm{ha}^{-1}$ was recorded from PGCP-6 and lowest, of $500.00 \mathrm{~kg} \mathrm{~h}^{-1}$, from PGCP-5. The control variety Pusa Komal showed $31.4 \%$ more yield than other control variety Pant Lobia-1 (Fig. 1). The varieties PGCP-6, PGCP-11, PGCP-12 and PGCP-14 recorded significantly higher grain yield than Pant Lobia-1, however, PGCP-4 and PGCP-13 were comparable with Pant Lobia-1. PGCP-6 and PGCP-12 gave $78.71 \%$ and $60.74 \%$ significantly higher yield than Pusa Komal. Among the varieties, the highest straw yield of $2584.07 \mathrm{~kg} \mathrm{ha}^{-1}$ was received from control variety Pusa Komal, which was 42.6 $\%$ significantly more than control variety Pant Lobia- 1 .

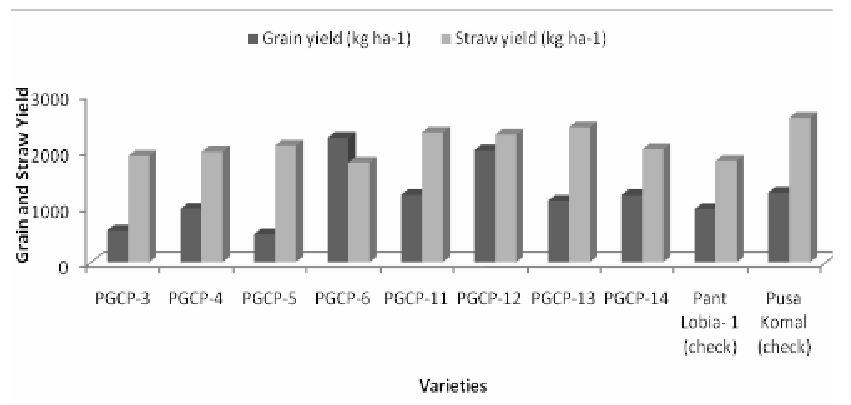

Fig. 1. Grain and straw yield of cowpea as influenced by cultivar differences

The lowest yield of $1782.22 \mathrm{~kg} \mathrm{ha}^{-1}$ was shown by PGCP-6, $44.99 \%$ and $29.7 \%$ less than control variety Pusa Komal and Pant Lobia-1, respectively. The varieties PGCP11, PGCP-12 and PGCP-13 were significantly better than control variety Pant Lobia-1. Cowpea varieties varied significantly with each other for nitrogen and protein content in grain. Pant Lobia-1 had significantly more nitrogen and protein than Pusa Komal (Fig. 2). The highest protein content was recorded in PGCP-4, which also had significantly more nitrogen content than the other varieties followed by Pant Lobia-1. PGCP-5 was significantly poor in nitrogen content than both control varieties.

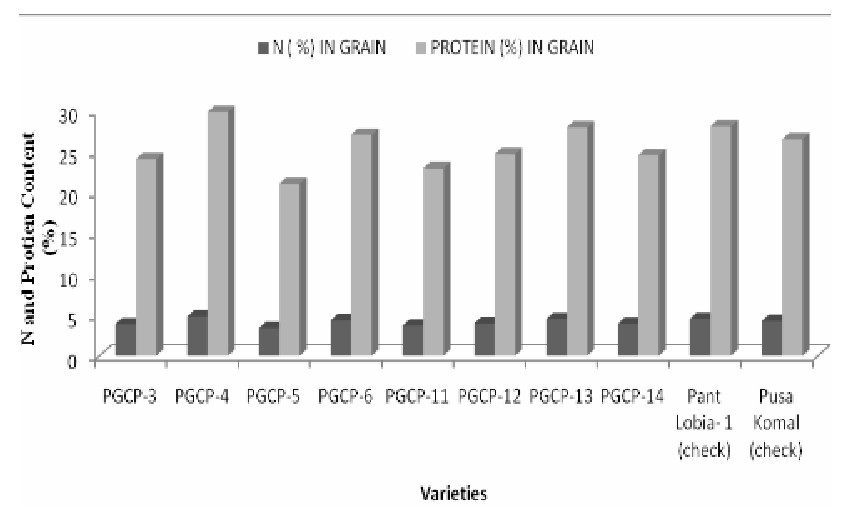

Fig.2. Nitrogen and protein content in cowpea grains as influenced by cultivar differences

The dehydrogenase activity of soil ranged from 196.55 to $266.87 \mu \mathrm{g}$ TPF $24 \mathrm{~h}-1 \mathrm{~g}^{-1}$ soil (Fig. 3). The highest and lowest activity was recorded with Pusa Komal and PGCP-4 respectively. The control varieties Pant Lobia-1 and Pusa Komal did not show significant difference within each other. None of the variety was significantly better than both control varieties. PGCP-3, PGCP-4, PGCP-5 and PGCP11 were inferior to both control varieties Pant Lobia-1 and Pusa Komal.

Significant differences $(\mathrm{p}<0.05)$ were observed in all the cultivars considered here. PGCP-4 was significantly better as it gave the highest number of nodules plant $t^{-1}$, nodule dry weight and protein content in grain than both the control varieties. Host-plant influence has been reported to have 
significant impact on the nodule number. Carroll et al., (1985) also reported that the nodule number and its distribution are largely dependent on host influence. As nodule size plays a major role in nodule dry weight and is reciprocally associated with the nodule number. Kurdali $e t$ al., (2005) observed that the number of nodules was also affected by plant genotype and bacteria. In this study, Pusa Komal (control variety) showed the highest plant dry weight (12.91) in comparison to other one. This can be supported by the fact that the plant dry weight is strongly influenced by specific combination of host genotype and bacteria (Shanmugasundaram, 1989). Interestingly, the control variety Pusa Komal exhibited the highest straw, while the highest grain yield was recorded for PGCP-6. The observation mentioned above may be attributable to the fact that the yield of the variety is actually dependent on its genetic potential and also, to some extent, depends upon the availability of essential nutrients and moisture content. Kurdali et al., (2005) also found that both dry matter yield and grain yield were affected by plant genotype and bacteria. The nutrient concentration in plant reflects an outcome of a physiological response that varies greatly from species to species. It also relies on the root growth and foliages of the plant. In the present investigation, PGCP- 4 recorded the highest nitrogen and protein content, which is due to the more numbers of nodules, this in turn shows that PGCP-4 is able is to fix more atmospheric nitrogen and further to convert it into protein. The observed significantly better performance of PGCP-4 and PGCP-6, show variable differences in the physiological structures, which made these cultivars readily able to absorb nutrients and water from the soil, and to effectively carry out the photosynthetic process and ultimately, to accumulate the higher amount of photosynthates. This observation was in congruence with the earlier reports of Fuhrmann and Vasilas (1994), which concluded that the cultivars respond differently to various environmental factors, and this differential response is primarily driven by their genetic makeup and their adaptive capabilities. The dehydrogenase activity is linked with the microbial activity, related with the physiological efficiency of microorganisms associated with plants, which is mainly host-dependent as they releases nutrients for microbes in the form of root exudates. Dehydrogense activity in soil is affecting plants due to their subsequent oxidation and reduction status during the nutrient and water absorption (Brzezinska et al. 1998).

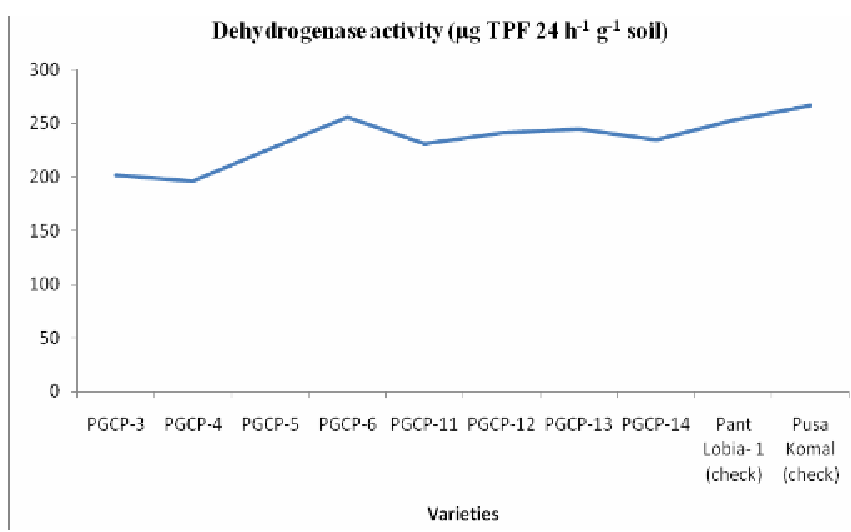

Fig. 3. Dehydrogenase activity ( $\mu$ g TPF $24 \mathrm{~h}^{-1} \mathrm{~g}^{-1}$ soil) in soil as influenced by cultivar differences

\section{Conclusions}

We evaluated the performance of eight cowpea cultivars using two standard control varieties and the study focused on the yield and other relevant traits. By contrast, the genotype PGCP-5 had the lowest values for parameters (nodulation, yield and protein content) chosen here for analysis. In addition, PGCP-6 and PGCP-12 differed significantly $(\mathrm{P}<0.05)$ in their performance and also had the highest yields over the others, suggesting that, based on the suitability of these two genotypes, these can be recommended to farmers for cultivation in Tarai region of Uttarakhand, India.

\section{References}

Agbogidi OM, Okonmah LU (2011 a). Performance of sweet pepper (Capsicum annuum L.) as influenced by weeding frequency. Intern J Sci Nat 2(4):119-122.

Brzezinska M, Stepniewska Z, Stepniewska W (1998). Soil oxygen status and dehydrogense activity. Soil Biol Biochem 30:1783-1790.

Carroll BJ, McNeil DL, Gresshoff PM (1985). A supernodulation and nitrate tolerant symbiotic soybean mutant. Plant Physiol 78:34-40.

Casida LE Jr, Klein DA, Santoro T (1964). Soil dehydrogenase activity. Soil Sci 98:371-376.

Fuhrmann JJ, Vasilas BL (1994). Variability among soybean genotypes in response to nodulation by a rhizobiotoxin producing strain of bradyrhizobia. Agron J (USA). 86(2):294-298.

Jackson ML (1967). Soil Chemical Analysis, Prentice Hall of Inc Englewood, Cliffs, New Jersey, 689 p.

Kurdali F, Nabulsi I, Mirali N (2005). Nitrogen fixation in mutant soybean lines inoculated with B. Japonicum strains. Agrochimica 49 (5/6):233-245.

Ogbo EM (2009). Effects of diesel fuel contamination on seed germination of four crop plants - Arachis hypogaea, Vignia unguiculata Sorghum bicolor and Zea mays. African J Biotechnol 8(20):250-253.

Philip RD, McWatters KH (1991). Contribution of cowpea to nutrition and health. Food Technol 9:127-130.

Shiringani RP, Shimeles HA (2011). Yield response and stability among cowpea genotypes at three planting dates and test environments. African J Agri Reso 6(4):32593263.

Shanmugasundaram S (1989). In: Global cooperation for the improvement of soybean research and development. p. 1939-1947. In: Proceedings World Soybean Res. Conf. IV. Pascale AJ (Ed.). Asociacion Argentina de la Soja, Buenos Aires, Argentina. 